Jurnal Professional FIS UNIVED Vol.1 No.1 Februari 2014

\title{
ANALISIS PENYAJIAN FOTO BERITA PADA SURAT KABAR HARIAN UMUM RAKYAT BENGKULU
}

\author{
Oleh : \\ FARDIANA \\ Dosen Tetap Prodi Ilmu Komunikasi Fakultas Ilmu Sosial UNIVED Bengkulu
}

\begin{abstract}
In journalistic work, photo has a very important role, such as beautify the pages and make the reader does not get tired reading. Each incoming photojournalism was selected by the photo editor to be considered whether a photo was appropriate and decent published in accordance with the written word. This research used observation and interview techniques to collect data. Data analysis techniques used by researcher was a descriptive analysis of data processing techniques. The photos presented Harian Rakyat Bengkulu were color photos and black and white photos. Based on the results of the discussion and explanation of this research from February 14 to March 14, it could be concluded that: The photos displayed on Harian Rakyat Bengkulu had various types which include spot News, Human Interest, Photo story, Feature Photo, and Photo Document. But of the many photos attached, most photos appearing in each edition were Spot News and stories.
\end{abstract}

Keywords: photo, news, newspaper

\section{PENDAHULUAN}

Media massa dituntut menyajikan sebuah informasi dalam bentuk berita yang harus memenuhi syarat kelengkapan agar para konsumen tertarik untuk membaca setiap berita yang disajikan media tersebut. Salah satu kelengkapan berita adalah adanya foto/gambar yang mendukung berita. Foto juga merupakan bukti penting dalam suatu kejadian yang akan di beritakan. Dengan adanya foto, orang lebih cepat memahami isi sebuah berita yang disajikan. Untuk itu, foto yang dihasilkan hendaklah benar-benar menyatu berita yang dibuat. Secara sudut pandang teknik pengambilan, foto dapat di defenisikan adalah gambar suatu peristiwa atau kejadian atau objek yang direkam oleh kamera. Adapun kelemahan dan kelebihan foto mempengaruhi nilai berita yang tulis, mempercantik dan memperkuat nilai berita, bisa dilihat kapan saja dengan jelas serta kelamahan foto adalah mudah memanipulasi, mudah usang, rusak dalam jangka waktu tertentu, dan kurang akurat (terbatas dengan waktu pembuatan).

Foto dalam kerja jurnalistik mempunyai peranan yang sangat penting ibarat masakan, foto dalam surat kabar atau majalah dapat diumpamakan sebagai bumbu penyedap, bahkan foto berperan untuk mempercantik wajah media cetak dan membuat pembaca tertarik untuk membaca. Apapun dan bagaimanapun bentuk foto itu, akan merupakan variasi yang sama sekali lain dengan tulisan yang hanya berisi hurufhuruf yang teratur rapi, namun demikian, sebagai penyedap tidak semua foto dapat dimasukan atau ditampilkan pada surat kabar atau majalah. Ada kaidah-kaidah yang 
harus dipenuhi dalam menampilkan foto pada surat kabar atau majalah.

Dalam menjalankan tugas dan profesi jurnalistiknya, wartawan tidak bisa dipisahkan dengan kegiatan foto jurnalistik atau foto berita. Seperti falsafah dari negeri China, yang mengatakan lebih baik melihat sekali daripada mendengarkan seribu kata. Sehubungan dengan itu, dalam rangka mengemban fungsi sebagai penyebar informasi pembaca, media surat kabar atau majalah merupakan bagian yang tak terpisahkan dari kegiatan foto jurnalistik.

Seperti halnya wartawan foto pada

Surat Kabar Harian Rakyat Bengkulu menginginkan sebuah foto berita yang mendukung beritanya, hal itu sesuai dengan fungsinya sebagai media massa cetak yang memegang peranan penting untuk menyampaikan atau memenuhi kebutuhan informasi, kejadian, pembangunan dan peristiwa sehari-hari dalam masyarakat. Akan informasi melalui tulisan dan didukung oleh foto jurnalistik agar memperkuat suatu nilai berita.

Dalam menghadapi persaingan dengan media cetak lain dikota Bengkulu, surat kabar Harian Rakyat Bengkulu dituntut untuk menyajikan foto berita sebaik mungkin secara profesional sehingga produk yang akan dihasilkan akan memenuhi selera pasar.

Beranjak dari uraian diatas penulis termotivasi untuk menganalisis bagaimana cara, penyajian foto berita atau foto jurnalistik pada Harian Umum Rakyat Bengkulu. Tujuan Penelitian sesuai dengan rumusan masalah yang dibahas yaitu untuk mengetahui cara prnyajian foto pada surat Kabar Harian Umum Rakyat Bengkulu.

\section{METODE PENELITIAN}

$\begin{array}{llr} & \text { Pelaksanaan penelitian ini } & \text { berlokasi } \\ \text { disurat Kabar Harian Umum } & \text { Rakyat } \\ \text { Bengkulu Kota } \quad \text { Bengkulu. } & \text { Teknik }\end{array}$

pengumpulan data dalam penelitian ini menggunakan dua sumber data yaitu studi lapangan dan studi pustaka. Dalam studi lapangan menggunakan teknik pengumpulan data dengan cara observasi yaitu pengamatan dilapangan dengan cara mengadakan pengambilan secara langsung pada obyek dan mengumpulkan data yang berhubungan dengan penyajian foto berita atau foto jurnalistik. Dokumentasi yaitu mengumpulkan data dengan menggunakan catatan dan laporan secara tertulis dari Harian Umum Rakyat Bengkulu. Wawancara/interview yaitu mengumpulkan data dengan cara melakukan tanya jawab kepada pimpinan dan karyawan yang bersangkutan. Studi pustaka dengan mempelajari buku-buku para ahli yang berkaitan dengan pembahasan masalah dan mengungkap sejarah dan lokasi pengamatan yang meliputi gambaran umum tentang Harian Umum Rakyat Bengkulu, mencari data lain yang dianggap perlu dan mendukung, diperoleh dari buku dan literatur yang ada diperpustakaan. Teknik analisa data yang dipergunakan penulis adalah teknik pengolahan data secara Deskriftif Analisis. Jalaludin Rakhmat (1993:25) menjelaskan penelitian deskriftif ditujukan untuk mengumpulkan informasi aktual secara rinci yang melukiskan gejala yang ada, mengidentifikasikan masalah, membuat perbandingan atau evaluasi, menentukan apa yang dilakukan orang lain dalam menghadapi masalah yang sama dan belajar dari pengalaman mereka untuk menetapkan rencanaa dan keputusan pada waktu yang akan datang, pengalaman mereka sehubungan untuk menetapkan rencana keputusan yang akan datang. Sehubungan dengan penulisan laporan ini, maka metode penulisan laporan deskriptif analisis ditekankan pada pengungkapan fakta yang digambarkan secara sistematis, faktual dan akurat tentang penyajian foto 
berita atau foto jurnalistik pada Harian Umum Rakyat Bengkulu.

\section{HASIL PENELITIAN DAN PEMBAHASAN}

Dari pengamatan penulis pada surat kabar Harian Umum Rakyat Bengkulu dalam setiap penyajiannya selalu menghadirkan foto-foto jurnalistik, banyaknya foto jurnalistik yang ditampilkan tergantung pada ruang yang tersedia pada masing-masing rubrik. Suatu gambar (Reporting Picture) harus menyajikan suatu informasi yang baru dan merupakan dokumen yang akurat. Ini merupakan segi jurnalistik dari sebuah gambar atau foto, sedangkan segi seninya ialah daya tarik dan keindahan gambar atau foto tersebut. Dua sifat khusus berita gambar atau foto berita ini tidak dapat dipisahkan.

Foto-foto yang dimuat pada surat Kabar Harian Umum Rakyat Bengkulu berasal dari berbagai sumber, antara lain untuk berita nasional berasal dari internet dan ada juga mengambil berita berkat kerja sama dengan LBKN Antara Bengkulu, sedangkan untuk berita lokal atau berita daerah berasal dari hasil liputan dan pantauan wartawan itu sendiri. Mengenai foto-foto yang disajikan Harian Umum Rakyat Bengkulu memiliki seorang fotografer yang menangani khusus bagian pemotretan, dimana foto-foto hasil karyanya akan dimuat atau ditampilkan pada surat kabar ini.

Setiap foto jurnalistik yang masuk ke redaktur foto Harian Umum Rakyat Bengkulu, terlebih dahulu diseleksi dan harus disesuaikan dengan berita yang akan ditulis dan kemudian akan dimuat atau disajikan pada harian ini. Tahapan penyeleksian foto jurnalistik pada surat kabar Harian Umum Rakyat Bengkulu terlebih dahulu di lakukan oleh redaktur, yang kemudian dikonfirmasikan ke redaktur halaman. Dalam penyeleksian tersebut akan dipertimbangkan mana foto yang layak terbit yang sesuai dengan berita tertulis. Serta penetapan berapa jumlah foto dan objek foto apa saja yang akan ditampilkan termasuk juga penentuan terhadap foto jurnalistik yang berdiri sendiri. Foto-foto yang disajikan pada Harian Umum Rakyat Bengkulu meliputi foto warna dan foto hitam putih.

Dalam setiap penyajian foto jurnalistik pada Harian Umum Rakyat Bengkulu, jenis foto yang ditampilkan kebanyakan spot news atau foto berita, foto human interst, foto cerita, foto olahraga, fot feature, dan foto dokumen.

Foto-foto jurnalistik yang disajikan Harian Umum Rakyat Bengkulu bersifat antara lain: (a) Sebagian besar foto yang ditampilkan bersifat akurat dalam artian foto yang ditampilkan bertujuan untuk menjelaskan secara utuh peristiwa yang terjadi. (b) Bersifat universal dimana foto yang ditampilkan dapat menjelaskan suatu peristiwa tanpa diperlukan bantuan media komunikasi lainnya misalnya tulisan keterangan. (c) Kompak dalam berarti berurutan sesuai dengan rentetan kejadian. Bersifat aktual dimana foto yang dihasilkan menjelaskan kejadian yang masih baru dan bukan foto yang bersifat nostalgia atau foto sejarah.

Foto merupakan salah satu media untuk berkomunikasi. Untuk itu dalam setiap penyajian foto harus memperhatikan kode etik jurnalistik. Begitu juga dengan foto yang disajikan oleh Harian Umum Rakyat Bengkulu. Media Rakyat Bengkulu memiliki syarat foto yang harus di perhatikan dalam setiap penyajian foto yaitu: (1) Foto/gambar harus jelas/tidak kabur, (2) Foto/gambar merupakan obyek yang menarik, (3) Foto/gambar harus mempunyai ide yang jelas, (4) Foto/gambar harus mudah dimengerti oleh pembacanya, 
Foto/gambar diambil dari sudut yang tepat, (6) Foto/gambar bukan fornografi, sadisme ataupun mengerikan, (7) Foto berita harus mempunyai nilai berita yang tinggi.

Penyajian foto pada surat kabar Harian Umum Rakyat Bengkulu bukan dimuat sekedar pengisi ruang kosong, akan tetapi tetapi ada makan tersendiri yang terkandung didalam setiap penyajian foto berita. Foto yang tersaji Harian Umum Rakyat Bengkulu berfungsi sebagai foto berita dan sebagai pendukung berita yang akan disajikan. Dalam setiap terbitnya Harian Umum Rakyat Bengkulu banyak menampilkan foto-foto jurnalistik.

\section{Analisis Foto Berdasarkan Fungsinya Sebagai Foto Berita.}

Gambar 1. Tanggal Terbit : 19 Feb 2011

Jenis Foto; Termasuk jenis foto berita "Spot News" yakni foto tunggal yang menyajikan suatu peristiwa yang berdiri sendiri.

Syarat Foto; Dilihat dari foto yang dibuat atau disajikan, sudah memenuhi syarat foto yang baik. Yakni gambar sudah jelas, mempunyai ide yang jelas, mudah dimengerti oleh pembaca, dan gambar diambil dari sudut yang tepat.

Sifat Foto; Foto yang ditampilkan sudah akurat karena merekam apa yang kelihatan dan menyajikan sebagaimana adanya secara universal yaitu menterjemahkan menggunakan bahasa komunikasi tertentu serta orang dapat dengan mudah melihatnya.

\section{Gambar 2. Tanggal Terbit : 22 Feb 2011}

Jenis Foto; Termasuk jenis foto "Human Interest" yaitu yang menampilkan masalah-masalah kemanusiaan dan kemasyarakatan. Foto tersebut disajikan sebagi foto tunggal yaitu tanpa keterangan yang berbelit-belit.

Syarat Foto; Foto disajikan kurang jelas karena tidak dapat menampilkan suasana yang utuh dan sulit dapat dimengerti oleh pembaca. Selain itu gambar diambil dari sudut yang kurang tepat sehingga mereduksi makna yang seharusnya ditampilkan.

Sifat Foto; Foto yang ditampilkan sudah memiliki sifat-sifat foto universal, visual, kompak, yaitu mudah merangsang reaksi orang untuk melihatnya.

\section{Gambar 3. Tanggal Terbit : 3 Maret 2011}

Jenis Foto; Termasuk "Spot News" atau foto berita yaitu foto tunggal yang menyajikan suatu berita yang berdiri sendiri tanpa keterangan yang berbelit. Tanpa ada keterangan kita akan tahu bahwa menceritakan tentang foto tersebut

Syarat Foto; Foto yang ditampilkan sudah memenuhi syarat-syarat foto yang baik. Yakni gambar sudah jelas, mempunyai ide yang jelas, mudah dimengerti oleh pembaca dan gambar diambil dari sudut yang tepat.

Sifat Foto; Foto mempunyai sifat yang akurat yaitu mempunyai kelebihan dalam dalam merekam peristiwa, mudah ditangkap atau dicerna bagi siapa saja yang melihatnya dan dapat merangsang orang untuk orang untuk melihatnya.

\section{Gambar 4. Tanggal Terbit: 07 Maret 2011}

Jenis Foto; Termasuk jenis foto "Spot News" atau foto berita.

Syarat Foto; Foto yang ditampilkan sudah memenuhi syarat foto berita yang baik, gambar yang disajikan jelas, obyek yang ditampilkan menarik serta mengandung nilai berita serta mudah diterjemahkan oleh pembaca karena diambil dari sudut yang tepat sehingga dapat menampilkan cerita yang utuh.

Sifat Foto; Foto yang yang disajikan mempunyai sifat yang akurat menyajikan sebagaimana mesti adanya yaitu merangsang 
orang untuk membacanya serta bersifat aktual.

Gambar 5. Tanggal Terbit : 21 Feb 2011

Jenis Foto; Termasuk dalam jenis foto "Feature" yaitu foto tunggal yang mengandung gagasan untuk disampaikan kepada orang lain.

Syarat Foto; Foto sudah memenuhi syarat foto yang baik. Foto yang di sajikan menarik dan memiliki nilai berita yang tinggi dan mudah dimengerti oleh pembacanya.

Sifat Foto; Foto disajikan sebagaimana adanya yaitu dapat dengan mudah merangsang reaksi orang untuk membacanya.

\section{Gambar 6. Tanggal Terbit: 03 Maret 2011}

Jenis Foto; Termasuk jenis foto "Spot News" atau foto berita yaitu foto tunggal yang menyajikan suatu berita berdiri sendiri.

Syarat Foto; Foto sudah memenuhi syarat-syarat yang baik dan memiliki ide yang jelas. Tanpa keterangan foto yang jelas, pembaca akan mudah terkecoh saat melihat foto tersebut.

Sifat Foto; Foto sudah disajikan secara aktual namun kurang detail dan tidak universal.

\section{Gambar 7. Tanggal Terbit : 21 Feb 2011}

Jenis Foto; Termasuk foto dokumen yang merupakan suatu rekaman langsung dari suatu peristiwa atau kejadian tanpa tipuan visual. Gambar ini komposisinya lebih formal dengan unsur yang jelas dan ditujukan untuk khalayak masa depan.

Syarat Foto; Gambar dokumen diatas sudah memenuhi syarat sebuah foto berita yang baik sebab gambarnya sudah jelas, mudah dimengerti oleh pembaca dan sudah diambil dari sudut yang tepat.
Sifat Foto; Foto sudah disajikan secara akurat yaitu merekam apa yang kelihatan dan menyajikan sebagaimana adanya secara visual yaitu mudah ditangkap bagi siapa saja yang melihatnya.

Analisis Foto Sebagai Pendukung Berita Yang Disajikan

\section{Gambar 8. Tanggal Terbit: 07 Maret 2011}

Jenis Foto; Termasuk foto "Essay" yaitu serangkaian foto atau gambar yang merupakan essay. Foto-foto tersebut menyajikan beberapa orang yang merupakan subyek dari masalah yang kita bahas.

Syarat Foto; Foto sudah disajikan dengan jelas, tidak kabur dan mudah di mengerti oleh pembaca dan mempunyai ide yang jelas

Sifat Foto; Foto sudah memenuhi syarat-syarat foto yang aktual, visual dan mudah dimengerti.

\section{Gambar 9. Tanggal Terbit : 24 Feb 2011}

Jenis Foto; Termasuk jenis foto cerita yaitu foto yang berusaha menceritakan atau laporkan suatu kejadian kepada pembaca.

Syarat Foto; Foto sudah memenuhi syarat foto yang baik, disajikan dengan jelas, dan tidak kabur, merupakan obyek yang menarik. Namun ide yang disampaikan kurang jelas Seharusnya foto tersebut lebih menunjukan pemandangan di lokasi.

Sifat Foto; Foto tidak universal karena menimbulkan kebingungan pembaca. Selain itu, foto tersebut tidak menjelaskan secara utuh peristiwa yang coba digambarkan.

\section{Gambar 10. Tanggal Terbit: 03 Maret 2011}

Jenis Foto; Termasuk jenis foto cerita yaitu foto yang menceritakan atau melaporkan suatu kejadian kepada pembaca

Syarat Foto; Jika dilihat dari jenis foto sudah cukup baik dalam menjelaskan 
maksud dari gambar. Namun, latar foto kurang mencerminkan kondisi kejadian.

Sifat Foto; Foto sudah akurat yang disajikan sebagaimana adanya, dan bisa merangsang orang untuk melihatnya karena pemandangan yang terlihat cukup unik.

\section{Gambar 11. Tanggal Terbit: 25 Feb 2011}

Jenis Foto; Termasuk jenis foto cerita yaitu sebuah foto yang melaporkan dan menceritakan suatu kejadian kepada pembaca

Syarat Foto; Foto mengandung ide yang jelas, gambar yang disajikan sudah jelas, obyek yang ditampilkan menarik dan di mengerti oleh pembaca.

Sifat Foto; Foto sudah akurat yaitu merekam peristiwa atau kejadian sesuai dengan apa yang dilihatnya dan disajikan sebagaimana adanya, namun masih kurang dalam menjelaskan identitas dari subyek foto dimana keterangan dituliskan

\section{Gambar 12. Tanggal Terbit: 7 Maret 2011}

Sifat Foto; Foto termasuk foto cerita yaitu sebuah foto yang melaporkan suatu peristiwa atau kejadian kepada pembaca.

Syarat Foto; Foto sudah mengandung ide yang jelas, mudah dimengerti oleh pembaca, obyek yang ditampilkan menarik serta memiliki nilai berita yang tinggi.

Sifat Foto; Foto sudah akurat yaitu merekam suatu peristiwa atau kejadian yang sebenar-benarnya serta mudah di mengerti oleh pembaca yaitu meransang orang untuk melihatnya.

\section{PENUTUP}

\section{Kesimpulan}

Berdasarkan hasil pembahasan dan penjelasan terhadap Foto Berita yang ditetapkan pada Harian Umum Rakyat Bengkulu, dari tanggal 14 Februari sampai dengan 14 Maret, maka penulis dapat menarik kesimpulan sebagai berikut: Fotofoto yang ditampilkan pada Harian Umum Rakyat Bengkulu mempunyai bermacammacam jenis yang meliputi Spot News, Human Interest, Foto Cerita, Foto Feature, Foto Dokumen. Tetapi didalam sekian banyak foto yang dilampirkan, foto yang paling banyak tampil disetiap eidsi Harian Umum Rakyat Bengkulu adalah Spot News dan cerita. Sebagian foto yang disajikan telah memenuhi syarat-syarat foto yang baik yaitu sesuai dengan pedoman serta. Panduan yang diterapkan antara foto yang dimuat dengan berita yang disajikan sudah berkaitan. Sedangkan sebagian lagi belum memenuhi kreteriah foto berita yang baik dilihat dari syarat dan sifat dari sebuah foto berita. Foto-foto yang disajikan di Surat Kabar Harian Umum Rakyat Bengkulu mempunyai dua fungsi yaitu sebagai foto yang berdiri sendiri dan sebagai foto pendukung berita yang disajikan. Pada setiap penerbitannya Harian Umum Rakyat Bengkulu tidak menyajikan foto-foto yang bersifat pornografi, sadisme ataupun horor, dan foto-foto yang disajikan merupakan obyek yang menarik serta disajikan dengan jelas. Foto-foto yang disajikan berasal dari berbagai sumber anatara lain: Fotografer, wartawan, internet, serta dari LBKN ANTARA Kota Bengkulu.

\section{Saran}

Berdasarkan kesimpulan diatas, maka penulis memberikan saran yang bermanfaat bagi Surat Kabar Harian Umum Rakyat Bengkulu yaitu: Surat Kabar Harian Umum Rakyat Bengkulu dimasa yang akan datang dalam menampilkan foto berita, harus lebih akurat dan aktual sehingga bisa sesuai dengan apa yang diberitakna. Kemudian dalam menampilkan foto harus jelas dan yang dapat merugikan namun tidak 
sampai menimbulkan suatu dampak buruk atau yang dapat merugikan masyarakat. Surat kabar Harian Umum Rakyat Bengkulu hendaknya membekali lebih banyak lagi keterampilan dan keahlian di bidang fotografi kepada, semua waratawan, khususnya fotografer agar foto berita yang dihasilkan memiliki nilai berita yang tinggi. Penambahan fasilitas penunjang bagi wartawan foto, seperti pengadaan laboratorium foto serta kamera digita dan peralatan pendukung fotografi lainnya seperti handycam. Pengaturan jumlah kolom dan frekuensi foto terbit hendaknya sesuai dengan peruntukan halaman agar foto-foto tersebut terlihat lebih pas dan tidak terlalu menganggu kenyamanan pembaca.

\section{DAFTAR PUSTAKA}

Jalaludin Rakhmat. 1993. Metode Penelitian. PT.Remaja Rosdakarya. Bandung
Assegaf Djafarah. 1983. Jurnalistik Penelitian Masa Kini. Ghalia Indonesia. Jakarta

Effendi Onong Uchjana. 1989. Kamus Komunikasi. Bandung

Payne Ice. 1985. Teori Komunikasi Massa Suatu Pengantar. Erlangga Jakarta Editor RM Soelarso

Patmono SK. 1996. Teknik Jurnalistik (Tuntunan Praktis Untuk Menjadi Waratawan). PT BPK. Gunung Mulia. Jakarta

Widodo. 1997. Teknik Menulis Surat Berita Di Surat Kabara Dan Majalah Penerbit Indah. Surabaya

Pawito Dan C. Sardjono. Teori-Teori Komunikasi. Buku Pemegang Kuliah Fisipol Komunikasi Massa Si Smemester Iv Surakarta: Universitas Sebelas Maret. 1994 


\section{LAMPIRAN}

\section{FOTO BERITA}

Gambar 1.

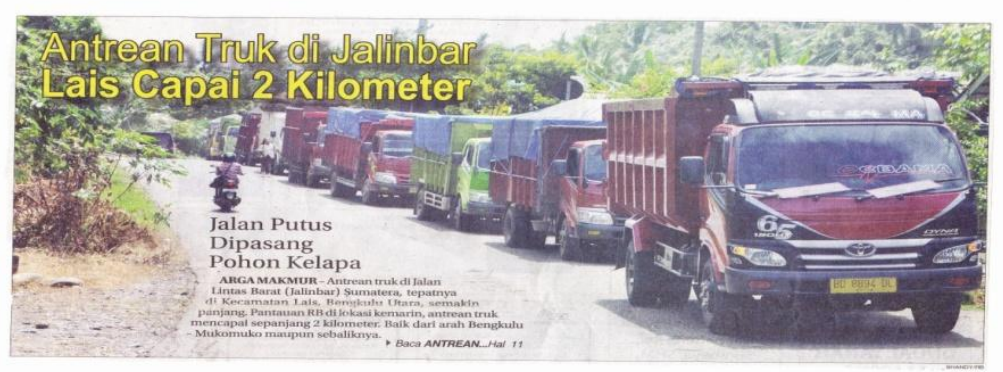

Gambar 2.

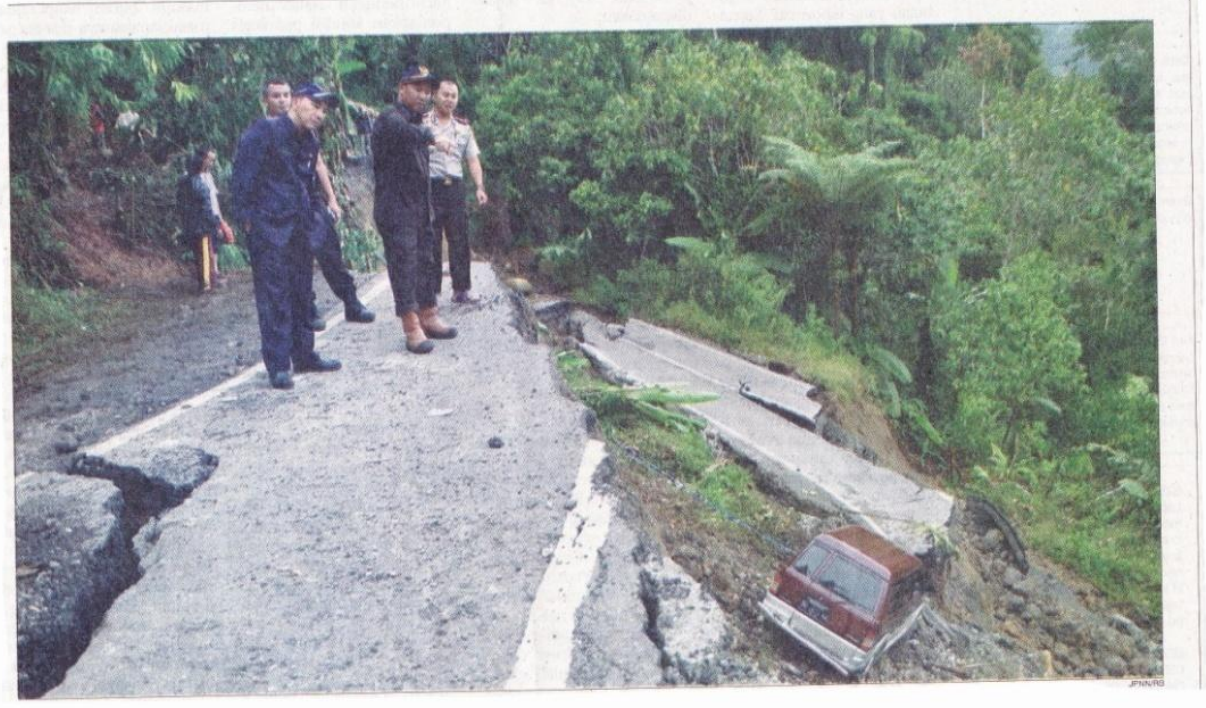


Gambar 3.

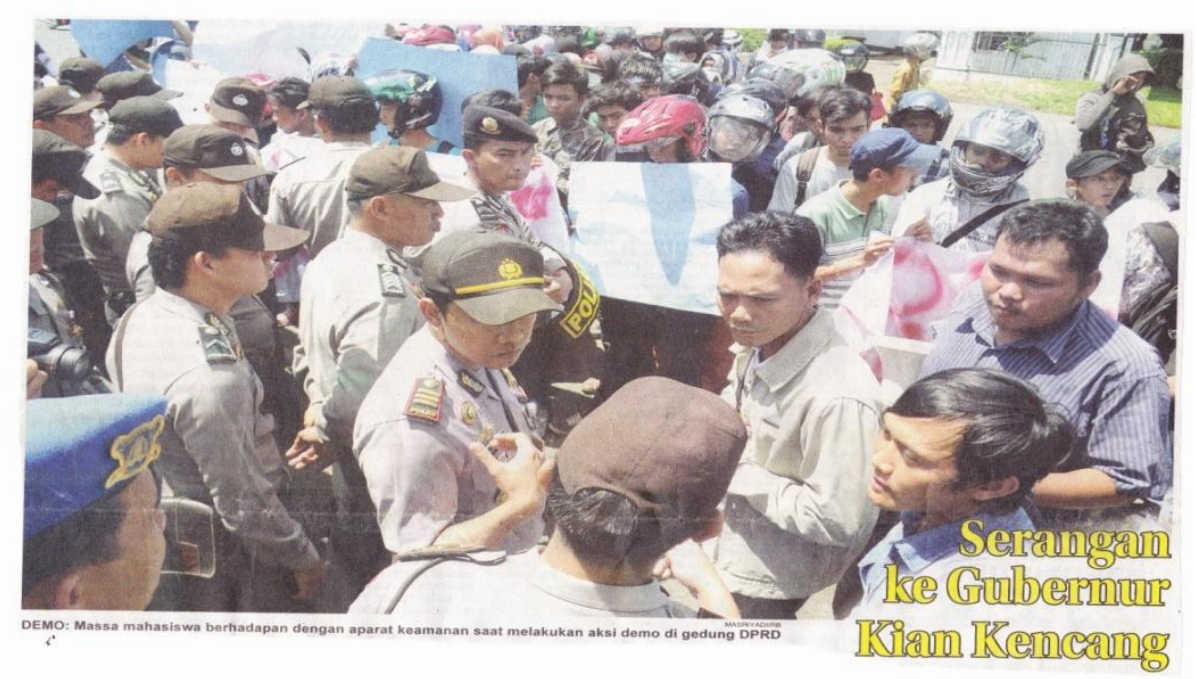

Gambar 4.

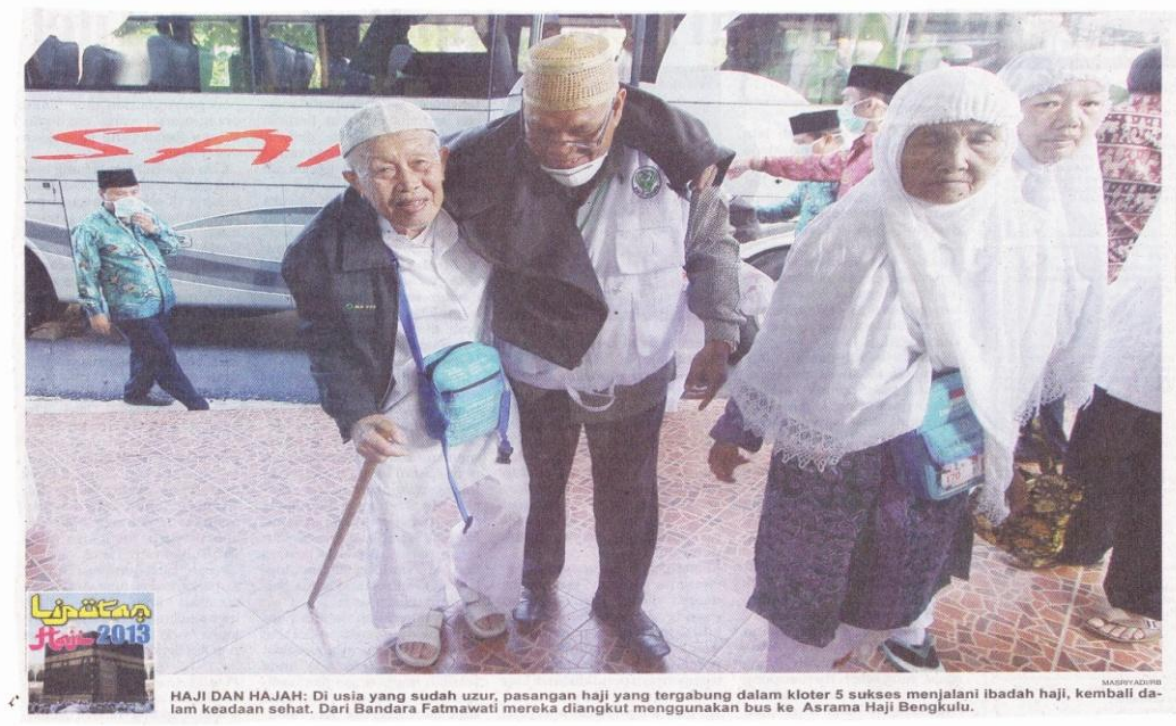




\section{Gambar 5.}

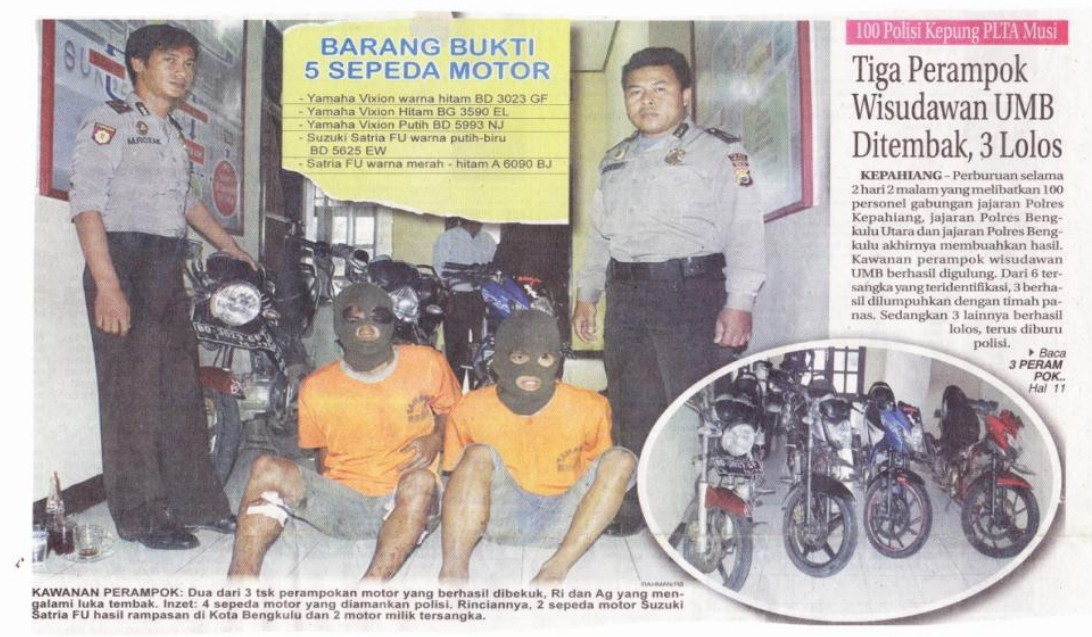

Gambar 6.

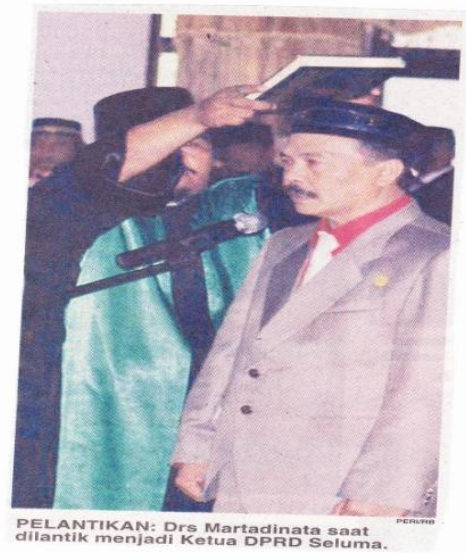


Gambar 7.

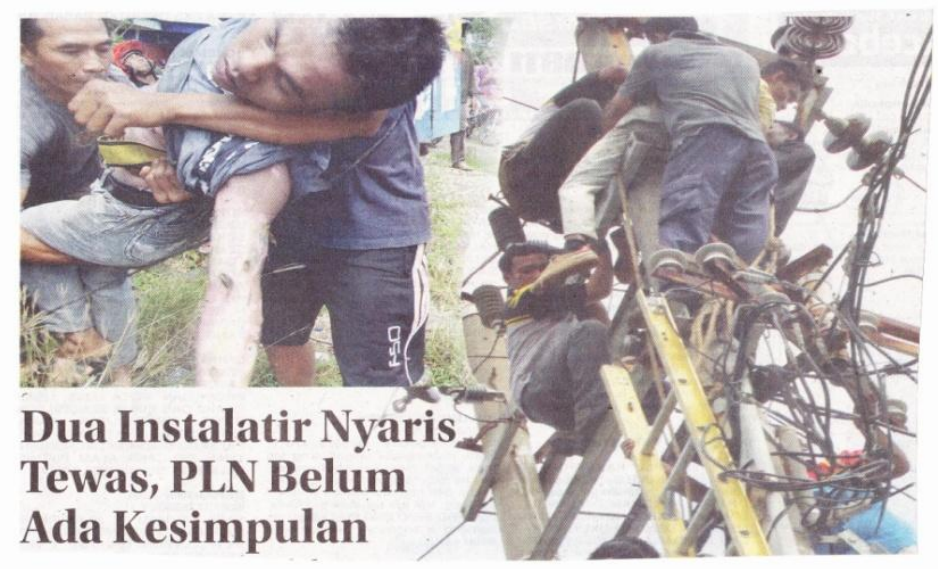

\section{FOTO PENDUKUNG BERITA}

Gambar 8.

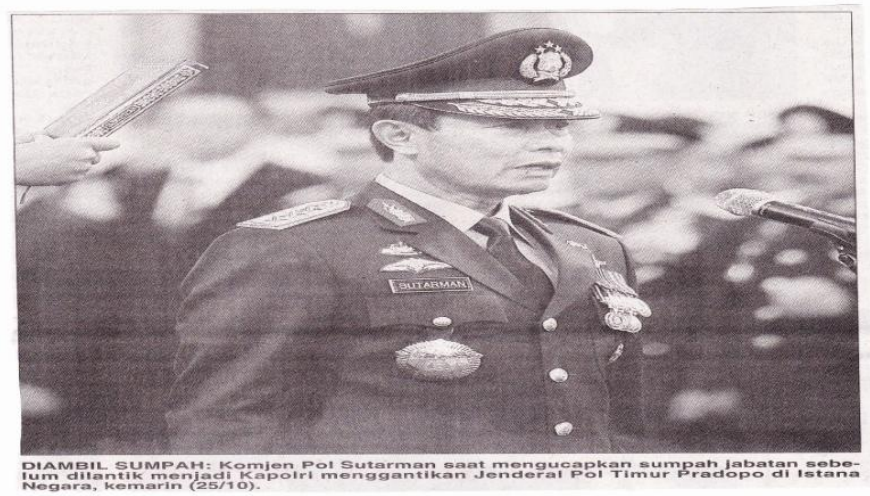


Gambar 9.

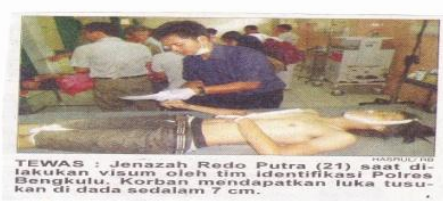

Gambar 10.

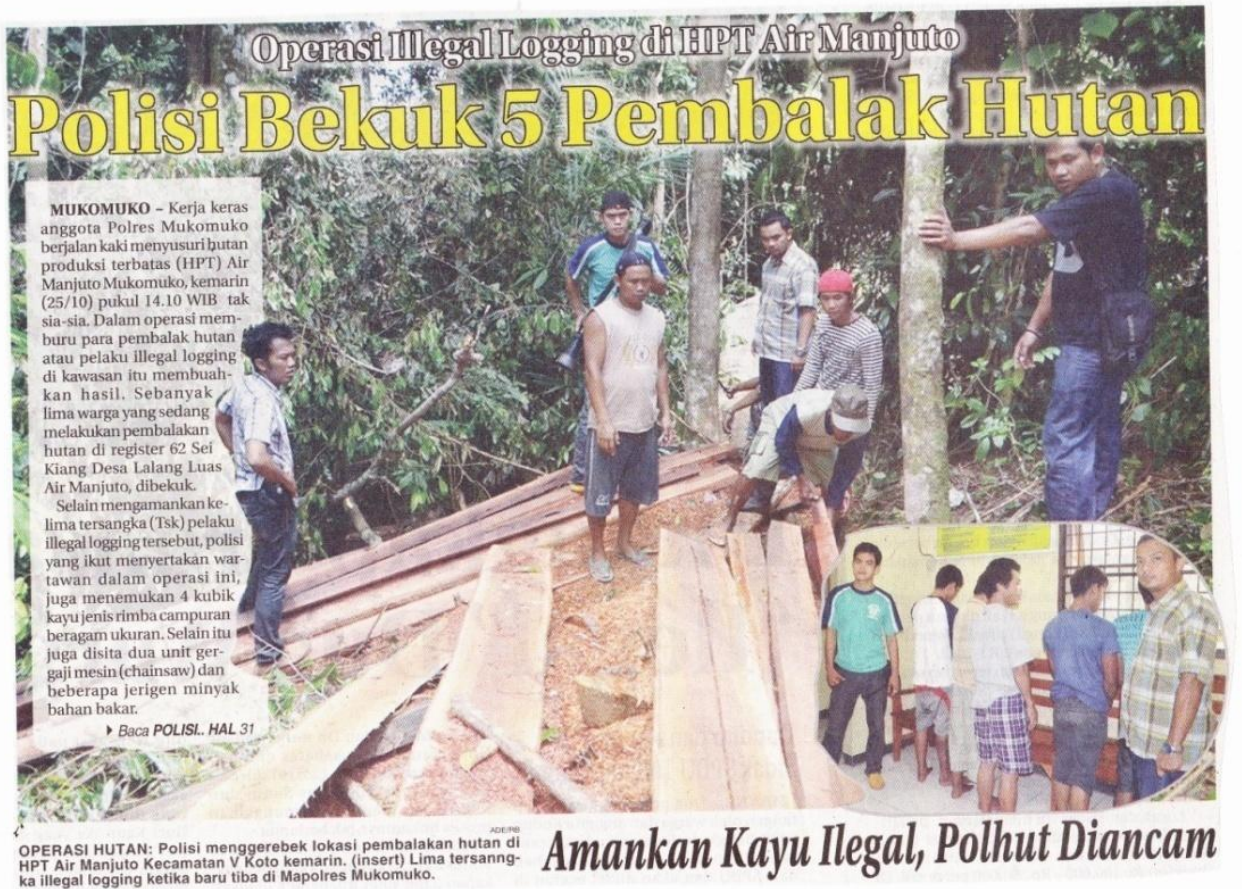


Gambar 11.

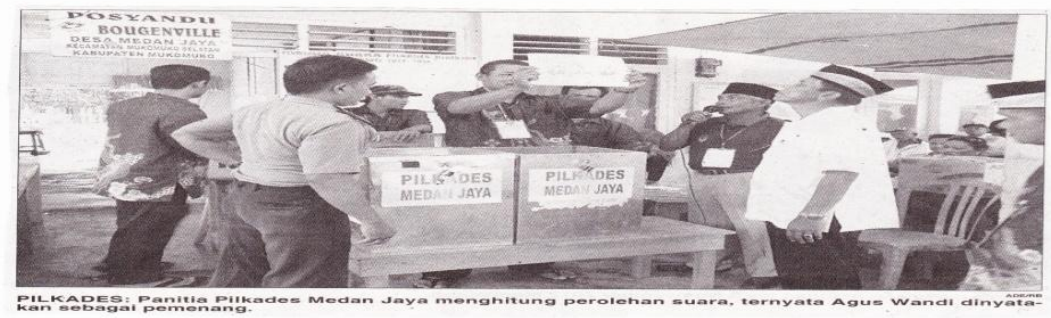

Gambar 12.

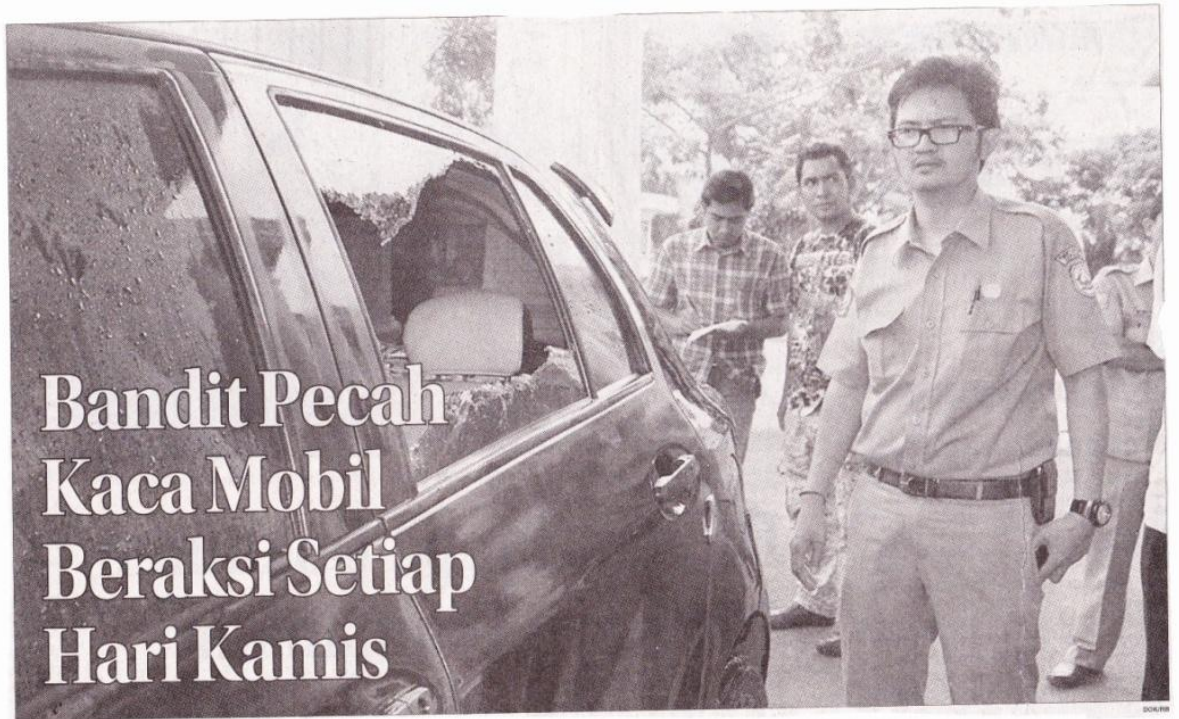

